\title{
NGOs and Civil Society: The Politics of Crafting a Civic Welfare Infrastructure in the Hu-Wen Period
}

Jude Howell ${ }^{*}$

\begin{abstract}
Since 2015 rights-based NGOs, lawyers, feminists and journalists have endured the most stringent crackdown since 1989. Simultaneously the Xi $\mathrm{Li}$ administration has pushed forward a series of laws, policies and regulatory changes to enable service-oriented NGOs to apply for government contracts to provide welfare services. This seemingly Janus-like policy of welfarist incorporation can be traced back to the $\mathrm{Hu}-\mathrm{Wen}$ period, often described as a lacklustre period, despite significant efforts to tackle issues of poverty and inequality. This article argues for a more balanced appraisal of this period by exploring in depth the complex politics underpinning efforts to pluralize welfare provision by involving service-oriented NGOs. It explores three sets of politics influencing this policy process: inter-institutional politics; state/non-state actor politics; and domestic/external politics. Furthermore, it considers processes of gradual institutional change adopted by key political actors to achieve these ends.
\end{abstract}

Keywords: NGOs; civil society; welfare; institutional change; security; policy processes

Under the $\mathrm{Xi}$ 习 administration, rights-based non-governmental organizations (NGOs), lawyers, feminists and journalists have experienced the most severe and concerted wave of repression since 1989. Simultaneously it has brought to fruition a series of laws, policies and regulatory changes to facilitate service-oriented NGOs competing for government contracts to provide welfare. The politics of this welfarist incorporation strategy that couples repression and selective incorporation traces its roots back to the $\mathrm{Hu}-\mathrm{Wen}$ period ( $\mathrm{Hu}$-Wen shiqi 胡温时期), when the seeds of a new civic welfare infrastructure were sown and watered.

When General Party Secretary Hu Jintao 胡锦涛 and Premier Wen Jiabao 温家宝 came into office in $2002-03,{ }^{1}$ poverty reduction was stagnating and political

* Department of International Development, London School of Economics and Political Science. Email: J.A.Howell@1se.ac.uk.

1 Wen Jiabao was on the Politburo Standing Committee in November 2002 but became Premier in March 2003 . 
concern about the potential effects of rising inequality on political stability was mounting. China's entry into the WTO in 2002 proved fortuitous for the new leadership. External trade and inward foreign investment expanded rapidly over the next six years as China "went global." With high growth rates maintained, at least until the 2008 global recession, central and local government coffers from tax revenues and extra-budgetary resources also burgeoned. As Christine Wong remarked, the $\mathrm{Hu}-\mathrm{Wen}$ period was a "golden economic era" that brought growth and economic prosperity to China. ${ }^{2}$

Nevertheless, the $\mathrm{Hu}-$ Wen leadership was not content with leaving poverty reduction to the vagaries of "trickle down"; rather, it initiated several key policy measures to reduce poverty and, to a lesser extent, inequality. These included the abolition of rural taxes, policies benefiting rural-to-urban migrants, reintroduction of the rural cooperative medical system, compulsory primary and junior high school, and policies to fashion a civic welfare infrastructure.

Yet, despite these efforts, the $\mathrm{Hu}$-Wen period has often been criticized for its lacklustre performance and paucity of path-breaking reforms. As Cheng Li commented, there was a "profound sense of disappointment and criticism" at the ineffectiveness of the $\mathrm{Hu}-$ Wen leadership. ${ }^{3}$ Indeed Li notes that some Chinese public intellectuals even described the $\mathrm{Hu}-$ Wen era as a "lost decade." In reviewing these years, Kerry Brown observes that the aspiration of reducing inequality had proved elusive, concluding that "nothing stands out as a genuinely historic legacy."4

This article aims to demonstrate some of the important steps taken during this decade towards reducing poverty and inequality by focusing on the politics pervading efforts to construct a civic welfare infrastructure. The term "civic welfare infrastructure" refers here to the regulatory environment governing the civic building blocks of welfare provision such as registered charities, foundations, unregistered NGOs, advocacy and rights groups, and community activism. An historical-constructivist approach to institutional change recognizes past institutional formations and shifting political and economic contexts as important factors influencing institutional change. ${ }^{5}$ Using the method of process tracing, the analysis follows the politics shaping civic welfare construction from the Deng Xiaoping 邓小平 period to the $\mathrm{Hu}$ Jintao administration through the lens of four initiatives. These are: revision of the regulations on foundations in 2004, experimental changes in registration requirements for social organizations from 2008 onwards, policies towards international actors supporting domestic social organizations, and finally, the drafting of a Charity Law.

The analysis adds to the literature on bureaucratic politics by highlighting the politics amongst different bureaucratic actors around security and welfare, statesociety relations, and domestic and external relations. ${ }^{6}$ The outcomes of these

2 Wong 2013.

3 Li 2013.

4 Brown 2013.

5 Hall and Taylor 1996.

6 Classic works here are Lieberthal and Lampton, 1992, Lampton 1987. 
politics led to both facilitating and constraining measures governing civic organizing. To capture the subtle nuances of institutional change it draws on and contributes to the literature on gradual institutional change, which has been mainly deployed in advanced democratic contexts. ${ }^{7}$ By applying this theory to the study of China, it demonstrates its usefulness in analysing institutional change in authoritarian environments.

The article begins with an overview of the regulatory and policy measures towards NGOs in the 1980s and 1990s. The second section explores the political dynamics underlying the four initiatives advanced during the $\mathrm{Hu}-\mathrm{Wen}$ period. The third section considers their legacy in civic infrastructure-building and contribution to welfare reform. The conclusion reflects on the contribution of the $\mathrm{Hu}-$ Wen leadership to crafting a civic welfare infrastructure, the politics underpinning this and gradual institutional change.

This research used the process tracing method to follow the twists and turns in key policies, speeches and documentation, paying attention to the subtle shifts in discourse around policy intent and content and the substantive changes in policies. This was triangulated with the analyses in the secondary literature relating to this period and to the policies affecting civic welfare infrastructure. Twenty semi-structured interviews lasting between an hour and two hours were conducted with key academics and government advisors in 2011 and 2012. The interviewees were selected because they had conducted research in the areas under investigation and/or because they were identified as scholars and experts providing advice to the government on the issues concerned and thus had a more intimate knowledge of the politics informing policy shifts. The interviews were cross-checked with the outcomes of the process tracing of key policies, speeches and documents and secondary literature to verify the findings.

\section{Crafting a Civic Welfare Infrastructure: 1980s and 1990s}

Developing a regulatory framework governing citizen organizing in China has been a tale of competing objectives. During the 1980s the two key contending objectives were first, to create an infrastructure of non-state, market-facilitating organizations such as trade and business associations, to which government functions could be transferred; and second, to maintain social ability and control dissent. From the mid-1990s onwards, a third objective has become increasingly salient, namely, to construct a civic welfare infrastructure as a basis for social welfare reform.

These competing objectives reflect different institutional and ideological interests. Specifically the push to emphasize controlling citizen organizing has, not surprisingly, emanated from state security institutions, including intelligence, 
policing and public security organs. The main impetus for promoting civic welfare groups emerges out of government agencies concerned with social policy matters, predominantly the Ministry of Civil Affairs (MOCA), but also the Ministries of Health, Education, and the State Council Leading Office for Poverty Alleviation. Both sets of institutions have interests in strengthening their professional capacities and relative power. These competing institutional interests within a broader context of often tense state-society relations have fuelled cycles of repression and relaxation, shaping both policies towards citizendriven public action and the pluralization of civic organizations.

These cycles of control and relaxation fuelled by competing motives and interests have characterized all three main periods of governance: Deng Xiaoping period (1978-1989), Jiang Zemin 江泽民 period (1989-2002) and $\mathrm{Hu}-\mathrm{Wen}$ period (2002-2012). They have been accompanied by different types of gradual institutional change prompted by processes of innovation, adaptation and repression. These include institutional layering, drift, conversion, "bounded adjustment" and "rule creation." By layering, Mahoney and Thelen refer to the within-system adjustment or revision of existing rules, whilst drift refers to rules that remain the same but may not be acted upon despite changing external circumstances. ${ }^{9}$ Conversion points to the strategic deployment of existing rules to achieve change. Whilst Campbell suggests that innovation and diffusion of ideas underpin institutional change, ${ }^{10}$ this study highlights the importance of repression, too. I thus further refine their concepts by adding the intermediate categories of "bounded adjustment" to refer to partial changes to existing regulations that reflect competing institutional motives and interests, "rule creation" where new rules are introduced where none previously existed or old ones of another politico-economic system were redundant, and "opportunistic layering," where in an institutional impasse local actors respond to higher-level cues to execute rule change. In doing so, I demonstrate how gradual institutional change theory can be applied in authoritarian contexts such as China.

In the following sub-sections I explore the politico-institutional and economic logics underpinning frameworks governing civic organizing during the Deng Xiaoping and Jiang Zemin periods of office. Despite a highly restrictive framework, civic organizing in practice continued to expand, albeit subject to constant contestation of state-society boundaries.

\section{Deng Xiaoping era (1978-1989)}

During the 1980s reformers focussed primarily on the economy, establishing systems to stimulate market growth and shift the state towards a more hands-off, "guiding" role. As the Party leadership reassigned certain state functions to the

9 Mahoney and Thelen 2010, 16-17.

10 Campbell 2004, 65. 
market, it had also to consider what to do with redundant state officials. In order to modernize and adopt advanced scientific and management practices, Party leaders cultivated a more positive environment for intellectuals, whose authority and skills were severely undermined during the Cultural Revolution. It is against this background of fundamental systemic reform that the emergence of more independent social organizations in reformist China has to be understood.

Illustrative of intellectuals' emerging role in policy processes was the influence of the renowned economist, Xue Muqiao, in promoting intermediary associations to transfer government functions, mediate relations with the market, and absorb retiring state personnel. ${ }^{11}$ Until the late 1980s social organizations were regulated under the 1950 Interim Provision on the Registration of Social Organizations. ${ }^{12}$ However, the growth of these organizations up till the late 1980s was not systematically monitored, leading to institutional drift. ${ }^{13}$ Social organizations registered with various government institutions, which had little oversight of their development. Most were ones that facilitated market reforms such as trade associations, professional organizations and learned societies, but there were very few welfare-oriented organizations. ${ }^{14}$

However, the rapid growth of more autonomous organizations took on a new dimension as the 1989 Democracy Movement unfolded. The 4th June crackdown on protestors in Tiananmen Square brought this first cycle of autonomous associational development to an abrupt end. In October 1989 the MOCA introduced the Regulations on the Management and Administration of Social Organizations that have shaped the development of social organizations since. These regulations instituted a regulatory framework that was restrictive rather than enabling of civic associational development. In particular three key elements proved useful to the Party/state in controlling social organizations. These are first, Article 3 requiring social organizations to identify a governmental sponsoring agency, thereby keeping social organizations under the proximate gaze of the state; second, Article 13 restricting "similar" registered social organizations operating in the same administrative jurisdiction, thus creating monopolies of representation in corporatist fashion; third, Article 19 preventing social organizations from forming regional branches, thereby thwarting coordinated, nationwide opposition."

This first cycle was instructive as it highlighted key political tensions around the state's role in ordering society. One key tension pivoted around the desire to facilitate market reform by creating new intermediary institutions whilst mitigating concern that expanding citizen engagement would undermine political stability. The institutional roots of this tension lay in market reform institutions

11 Xue Muqiao 1988.

12 Social organizations (shehui zuzhi) are defined in the 1998 regulations as "non-profit organizations voluntarily created by Chinese citizens." Over the years the term has often been used interchangeably with NGOs.

13 White, Howell and Shang 1996.

14 Pei 1998: 292, 294. 
such as trade, commerce and industry, and security and propaganda institutions. At the leadership level they also were an expression of continuing ideological struggles around economic reforms between the reformists and the conservatives.

\section{Jiang Zemin period (1989-2002)}

The second main cycle of more autonomous organizational development that roughly corresponds to the Jiang Zemin period of office (1989-2002) followed a similar path of relaxation of government controls followed by tighter restrictions. Politico-institutional and economic logics underpinned this second cycle. In 1995 China's hosting of the Fourth World Conference for Women triggered the emergence of social organizations addressing gender and women's issues. ${ }^{15}$ International NGOs and foundations, bilateral development agencies, and embassies played a key role in supporting new, independent women's groups and assisting the Party-linked All-China Women's Federation (ACWF) to gain exposure to global feminist activism. However, this was matched by the intermittent closure of salons, surveillance of new groups, and government suspicion of foreign funders' motives. This flourishing of women's organizations had a ripple effect on civic organizing that continued up until 1998 when the 1989 regulations on social organizations were amended.

By the late 1990s some of the negative social effects of economic reform were leading to rising social discontent. State enterprise reform from 1993 onwards led to millions of lay-offs, provoking large-scale protests, especially in north-east China. ${ }^{16}$ As workplace-based urban welfare provision disintegrated, new forms of urban poverty arose. Alongside the continual throb of strikes in coastal areas, unrest grew in the countryside, often violent, ${ }^{17}$ due not least to excessive fees. Added to this, in April 1999 falun gong adherents surrounded the Zhongnanhai, posing a highly symbolic challenge to the Party. ${ }^{18}$ In June the extra-legal security agency Office 610 was established under the Central Leading Group on Dealing with the Falun Gong to monitor the organization. It was against this background of a perceived political threat to its authority that the CCP reasserted its control over the associational sphere. The MOCA came under substantial pressure to take stock of registered social organizations and place the house in order. ${ }^{19}$

In 1997 the MOCA issued the "Notice Concerning Investigating and Dealing with Illegal Social Associations." This heralded the start of a process to separate the "wheat from the chaff." All social organizations were required to re-register with their local Civil Affairs Office, dampening any initiative to establish new

15 Howell 1997; Kaufman 2012.

16 Lee 2007.

17 Walker 2006; Day 2013.

18 Ostergaard 2004.

19 Ostergaard 2004. 
social organizations or undertake activities. The revised 1998 "Regulations Concerning the Registration and Supervision of Social Organizations" - a type of layering - stipulated stricter conditions for registration, leading to a decrease in social organizations from 200,000 in 1998 to 136,841 in 2000, almost a third less than the 181,060 groups registered in $1993 .^{20}$

However, the Party/state did not intend to completely obliterate civic organizing, but rather instrumentally mould it to assist welfare reform, which required changes both on the demand and on the supply side. On the demand side, the government had to reduce urban residents' reliance on the state and push them to become active citizens and contributors to social insurance. On the supply side, the government needed to open up welfare provision to profit and non-profit providers and get enterprises to pay into social insurance. However, the regulatory frameworks governing social organizations continued to be a straitjacket on the expansion of non-governmental service provision.

During the Jiang Zemin period there were patchwork efforts to reform the welfare system, mainly through the development of insurance systems for medical provision and pensions. ${ }^{21}$ These "supportive reforms" were linked not only to the acceleration of state-enterprise reforms but also to stability. As Jiang Zemin stated at the 15th Party Congress, "We must balance the intensity of reform, the speed of development and people's ability to sustain them, promoting reform and development amid social and political stability and securing social and political stability through reform and development."

However, welfare reforms proceeded in an ad hoc and piecemeal fashion during this period, more "by default than design." 22 By the end of the 1990 s central Party leaders were increasingly aware that reform efforts needed to focus not only on economic systems but also on welfare to ensure social stability. Hence the revised 1998 regulations governing social organizations were accompanied by rule creation, engendering four new regulations on private non-enterprise institutions that provided welfare services, foundations, donations and foreign chambers of commerce. ${ }^{23} \mathrm{Up}$ to this point there were only eight Chinese foundations in operation, most being government-founded and run, along with a handful of foreign foundations. ${ }^{24}$ These regulations were intended to address gaps in welfare provision, making it possible to establish a private foundation through a corporate or family gift, and thereby widen the net of service providers, attracting alternative sources of philanthropic finance. The Party was targeting China's new stratum of entrepreneurs as a source of revenue. To this end Jiang Zemin had artfully brought entrepreneurs into the Party fold in 2001 to endorse

20 Private communication, February 2002; Howell 2007.

21 Chan, King and Phillips 2008; Lu and Feng 2008.

22 Saich 2008.

23 These regulations were: 1998 "Provisional Regulations for the Registration and Administration of Private Non-Enterprise Institutions', “Administrative Regulations on Foundations', "Provisional Regulations on Foundations' and 1999 "Law of Donations on Public Welfare."

24 China Development Brief 2004. 
their importance in economic development and stave off any challenge to the Party. ${ }^{25}$ By encouraging entrepreneurs to contribute to welfare financing through philanthropic initiatives, the Party sought to extend the sources of welfare financing and appease resentment at widening disparities.

However, Jiang Zemin's endorsement of the potential of social forces was balanced by a call for Party vigilance over social organizations. In his speech celebrating the 80th anniversary of the CCP in July 2001, he underlined the importance of Party leadership over NGOs. Again, at the 16th Party Congress in 2002, he stated, "We must combine punishment and prevention ... take comprehensive measures to maintain law and order and improve social management so as to keep public order."

Whilst this second cycle ended with the reassertion of Party control and more restrictive registration regulations, it also reflected an emerging shift in policy thinking to prioritize not only economic growth but also welfare reform. The double-edged nature of these regulations mirrored the push-and-pull of tensions within the central and local leadership and between particular state institutions around domestic security and welfare concerns. The initial empirical impact was a substantial decline in the number of social organizations registered.

\section{Politics of Civic Welfare Construction in the Hu-Wen Period, 2002-2012}

The leadership change in 2002 brought new priorities, agendas and opportunities for shaping a civic welfare infrastructure that built upon past measures, indicating a degree of path dependency in institutional change. It was during the $\mathrm{Hu}-\mathrm{Wen}$ decade that a more systematic effort was made to address welfare issues. The emphasis on urban industrialization during Jiang Zemin's office had aroused considerable discontent amongst rural citizens. The breadth and persistence of rural protests and strikes in coastal factories put considerable pressure on the new leadership to address more systematically poverty and inequality. Rural poverty remained in absolute and global terms still substantial, with estimated numbers varying from 23.6 million (end 2005) to 150 million, ${ }^{26}$ depending on how poverty was measured and appropriated in political discourse.

$\mathrm{The} \mathrm{Hu}-$ Wen leadership initiated a raft of reforms aimed at improving rural conditions, ranging from the abolition of agricultural taxes to the reintroduction of rural cooperative medical care. How much this was due to the personality and beliefs of $\mathrm{Hu}$ Jintao and Wen Jiabao is difficult, if not impossible to assess, given the opacity of internal Party politics and elite consensus policymaking. Also, $\mathrm{Hu}$ Jintao strategically nurtured a highly controlled image of himself devoid of any ego. ${ }^{27}$ This may have enabled $\mathrm{Hu}$ to advance rapidly up the Party ladder but also calls for caution in overemphasizing the power of any individual leader to 
shape policy. Nevertheless, the leadership tropes that come to symbolize particular constellations of leadership are important framing devices for institutional change. Whilst Jiang Zemin had reoriented Party ideology through the "Three Represents" concept that paved the way for entrepreneurs to enter the Party, $\mathrm{Hu}$ and Wen took a different steer.

Specific leadership tropes of the $\mathrm{Hu}-$ Wen period such as "putting the people first," "harmonious society" and "inclusive development" provided the ideological frame to address inequality through social welfare and turn away from a singular focus on growth. Inclusive development and harmonious society signified a reality of widening disparities and growing discontent that could delegitimize the Party. The new-fangled notions of "social management" and "social construction" introduced in the fourth and sixth Plenary Sessions of the 16th Party Congress in 2004 and 2006, and stated more forcefully in the 17th Party Congress in $2007,{ }^{28}$ signalled more changes ahead, including enhancing the supply of non-governmental welfare providers and cultivating a cadre of professional social workers.

Apart from political and ideological factors, China's WTO entry provided favourable economic conditions for pursuing goals of well-being and economic prosperity. Whilst WTO entry was largely advanced during the Jiang Zemin period, $\mathrm{Hu}$ and Wen reaped the economic benefits of China "going global," inheriting an economy that continued to enjoy double digit growth and became in 2010 the world's second largest economy. Local governments, especially in coastal areas, took advantage of new global economic opportunities to expand production. This was an important pre-condition for refashioning China's social welfare system.

It was in this shifting ideological, political and economic context that government initiatives to establish a civic welfare infrastructure have to be understood. Developing a civil society that could play a role in welfare services provision had constantly been thwarted by the unresolved contradictions in the Party-state's approach to civil society. This unresolved dilemma lay in how to balance social control with fostering non-governmental providers to assist in developing a new model of social welfare. The emerging $\mathrm{Hu}-\mathrm{Wen}$ vision of civil society was one that embraced technical, service-oriented civic groups but shunned those engaged in advocacy, rights-work and political causes. Though Jiang Zemin sought to engage social actors in welfare, primarily entrepreneurs as financial providers, concerns about social stability overrode moving determinedly to a more enabling environment for civic organizing. The $\mathrm{Hu}-\mathrm{Wen}$ leadership drew on this legacy to shift the balance more strategically towards social forces and service delivery. Indeed, as seen in the initiatives to craft a civic welfare infrastructure below, it is during the $\mathrm{Hu}-W e n$ period that the political contours of inter-institutional, state-society, and domestic-external politics shaping civic organizational development surface more clearly. 


\section{Regulations for the Registration and Management of Foundations, 2004}

There were two main drivers behind the introduction of the Regulations on the Management of Foundations (jijinhui guanli tiaoli 基金会管理条例) 2004, which, as a refinement of the 1998 regulations, marked a process of institutional layering. First, concerned about the potential impact of private entrepreneurs' growing wealth on income inequalities and stability, the $\mathrm{Hu}-$ Wen leadership sought to ensure some redistribution of this new-found wealth to public causes. Second, by encouraging entrepreneurial philanthropy, the Party/state could establish an alternative but supplementary pillar of welfare financing and balance socio-economic interests to foster a "harmonious society."

The drafting process for the 2004 Foundations Regulations extended over several years, involving consultation with governmental foundations, legal experts and scholars. The new Regulations aimed to establish transparent governance to strengthen public confidence in foundations. They also provided a more comprehensive regulatory framework, separating out foundations from not-for-profit enterprises and social organizations. The most significant achievement was distinguishing between public fund-raising foundations, most being government-organized, and private philanthropic foundations, which were not permitted to raise public funds. In doing so they gave the go-ahead for the expansion of private foundations by philanthropic entrepreneurs such as Ma Huateng, founder of Tencent Foundation, a small minority of which would a decade later fund social organizations addressing marginal interests. As with social organizations, the Regulations required foundations to identify a government sponsoring agency to supervise their work, placing limits on their autonomy and growth. ${ }^{29}$

However, as with all drafting processes, what is omitted from the final version can be a useful pointer for understanding the politics of institutional change. In this case earlier drafts did not require foundations to identify a sponsoring government agency. Moreover, if international organizations could not find a government sponsor, MOCA could be both the sponsoring and registration agency. ${ }^{30}$ Whilst these did not become provisions in the new Regulations, they were significant in two respects. First, they indirectly anticipated the relaxation of registration requirements for social organizations that was to follow in 2008. Second, they addressed both domestic and foreign foundations for the first time, thus acknowledging a continuing role for foreign foundations in China, albeit still vulnerable to potential closure. Nevertheless, the fact that international foundations remained barred from raising funds within China suggested continuing reluctance to grant them a major role in welfare financing and provision. 


\section{Sub-contracting and relaxation of registration restrictions}

The second major initiative came with the experimental relaxation of the registration regulations for selected social organizations to facilitate governmental subcontracting of service provision. As will be seen, this "bounded adjustment" reflected a compromise position between contending interests and motives. Up to this point continuing attempts by reform-minded MOCA officials and legal scholars had been unable to soften the highly restrictive registration framework, encountering resistance from public security officials and conservative, risk-averse officials. Indeed, this was becoming counter-productive for both mobilizing civic energy in welfare provision and in maintaining social control. Several developments in the first five years of $\mathrm{Hu}-W e n$ 's office hastened moves towards loosening these tight regulatory restrictions.

First, local government officials were already turning a blind eye to the growth of non-registered, non-governmental welfare-focused organizations. ${ }^{31}$ Institutional drift had spawned a stratum of NGOs that bypassed the MOCA, registering as businesses with the Industrial and Commercial Bureau, whilst two million or more civic groups ostensibly remained unregistered. ${ }^{32}$ Organizations catering to losers under reform increased from the late 1990s onwards. ${ }^{33}$ From local officials' perspective, these organizations were filling gaps in service provision due to weak government capacity and/or unwillingness to deal with stigmatized groups such as drug addicts and people living with HIV/AIDs. ${ }^{34}$ Second, this growth reflected the ingenuity of civic society actors in circumventing restrictive regulations by registering as non-profit enterprises, pursuing activities through donor-funded projects, affiliating to a research institute, or just not registering at all.

Third, local Civil Affairs officials sympathetic to civic groups playing a supplementary role in welfare provision took a more relaxed approach to registration. As a result there was an explosion in growth of registered social organizations during the $\mathrm{Hu}-\mathrm{Wen}$ period, from 200,000 in 2001 to just over 400,000 by $2008 .{ }^{35}$ The realm of civic organizing was visibly expanding, despite stringent regulatory controls, reflecting the Party-state's inability to impose a corporatist system of intermediation. ${ }^{36}$ Indeed, a MOCA official commented in an interview that there was an urgent need to tidy up the non-profit sector. ${ }^{37}$

The legislative and political basis for the initiative to ease registration conditions to facilitate welfare services sub-contracting could be traced back to the early millennium. The passing of the 2001 Contract Tendering Law and the

31 Spires 2011, 12

32 Wang and Sun 2010.

33 Precise figures are not available, partly because many groups concerned with marginalized interests are not registered.

34 Wilson, 2015; Hildebrandt 2013.

35 Wang and Sun 2010, 156-57.

36 Howell 2012, 2013.

37 China Development Brief: 2004, 6. 
Procurement Law a year later provided a legal framework for government procurement processes. ${ }^{38}$ However, there were no specific laws or regulations on the sub-contracting of welfare services, only "guiding opinions" (zhidao yijian 指导意见), which have less authority than a law, regulation or notice (tongzhi 通知). Though there had previously been some transfer of governmental economic functions to sectoral associations, this was not actually for the subcontracting of service provision and did not involve a formal contracting process.

The Asian Development Bank played a key role in promoting the idea of subcontracting service provision to NGOs from 2002 onwards. ${ }^{39}$ It supported the first pilot project tendering for service provision contracts in Jiangxi province in 2005. The China Poverty Alleviation Fund put aside one million yuan for tendering purposes, and NGOs could then bid for poverty reduction projects at village level. Similarly Shaanxi provincial government made available 20,000 yuan for tendering service provision to social organizations. ${ }^{40}$ By 2007 Jiangsu provincial government had already begun to sub-contract service provision for people with TB, migrant workers and care of the elderly. In 2007 the Asian Development Bank signed another contract with the MOCA to extend these experiments in sub-contracting service provision to social organizations. More formal experimentation with a view to scaling up followed from 2007 onwards in Shenzhen, Beijing and Guangzhou. ${ }^{41}$

These initiatives gained added impetus from growing public and government awareness of the positive role that NGOs and volunteers played in the Wenchuan earthquake in 2008. This fostered a more favourable climate for MOCA officials to amend the regulatory framework governing social organizations. ${ }^{42}$ However, government security and intelligence agencies watched with trepidation the ease with which citizens spontaneously mobilized for disaster relief, fearing that such civic energy could also be deployed for anti-regime purposes, particularly in the forthcoming Olympic Games. ${ }^{43}$

In this heady environment of public praise for civic engagement, the MOCA pushed ahead with experimental institutional change. In July 2009 it signed a Co-operative Agreement on Advancing Integrated Reforms in Civil Affairs with Shenzhen municipal government. A key component was a regulatory revision to allow social organizations to directly register with the municipal level of Civil Affairs. Chengdu, Beijing, Shanghai and Guangdong followed suit with their own local experiments with the registration and management requirements of social organizations. ${ }^{44}$ In February 2010, for example, the Beijing municipal government issued regulations allowing social organizations in Zhongguancun

38 Interview, academic, Beijing, July 2012.

$39 \mathrm{Jia}$ and $\mathrm{Su} 2009$.

40 Interview, social policy academic, Beijing, 23 July 2012.

41 Interview, social policy academic, Beijing, 23 July 2012.

42 Teets 2009; Simon 2009.

43 Shieh and Deng 2011.

44 ICNL 2013. 
Science Park to register directly with the civil affairs bureau. ${ }^{45}$ In 2010 the Shanghai municipal government issued a document stating that sub-contracting could be done with sectoral associations, cooperatives, community-level services, and welfare services.

Innovation in civic welfare provision got a further boost when General Secretary Hu Jintao introduced the idea of "social management" at the 23rd collective study session of the Politburo in September 2010.46 Thereafter Chinese leaders and the media repeatedly emphasized this new concept. Hu reiterated the idea again in his keynote speech at the Central Party School in February 2011, at which he announced that "social management" (shehui guanli 社会管理) was to be a priority. This would involve eight main tasks, such as "supporting people's organizations," and improving the management of services for marginalized groups. ${ }^{47}$

This ambiguous term provoked varied responses amongst leaders at all levels, academics and social media, with some optimistically interpreting this as central government support for citizens organizing around public affairs and welfare, whilst others saw this as an omen of greater social control. ${ }^{48}$ This ambiguity stemmed partly from Jiang Zemin's use of the term "social management" in relation to public order. For example, in his November 2nd speech at the 16th Party Congress in 2002, Jiang stated, "We must combine punishment and prevention ... take comprehensive measures to maintain law and order and improve social management so as to keep public order." The double-edged nature of the term has given space for protagonists of respectively greater social control and greater civic engagement to act accordingly.

Illustrative here is the move by Zhou Yongkang 周永康, then chair of the Central Committee for Comprehensive Management of Public Security, shortly after Hu's 2011 speech, to rename this body as the "Central Committee for Comprehensive Social Management." At the same time academics gave the term a more liberal interpretation, whilst local-level officials have also paraded their successes as examples of "innovative social management." 49 Social management became more deeply embedded as a Party priority in the "Outline of the 12th Five-Year program for Economic and Social Development," which was adopted at the 11th NPC in March 2011, in which a whole section, Part IX, was devoted to social management.

Within this context of central government support for involving social forces in welfare provision, the MOCA and innovative local leaders were well positioned to move ahead with crafting a more enabling regulatory framework for social organizations. After reviewing early experiments in Shenzhen, Beijing and Guangzhou, in July 2011 the MOCA issued new regulations governing the

48 Cohen 2011; Interviews, academics, Beijing, February 2014.

49 Jing and Gong 2012. 
registration of social organizations in the fields of charity and welfare that would pave the way for the sub-contracting of services to selected social organizations. Thereafter 19 provinces were given the green light to initiate pilot programmes for direct registration. Beijing City government received 100 million yuan from the central government for sub-contracting service provision, though not as much as they had hoped for. ${ }^{50}$ By July 2012 Shanghai, Shenzhen, Dongguan, Yunnan, Guangxi, Xinjiang and Sichuan were practising sub-contracting service provision.

Dynamic provincial leaders such as Wang Yang 汪洋, then governor of Guangdong province, took advantage of this apparent opening, not only to encourage easier registration of social organizations but also to push comprehensive reforms of mass organizations, enabling the ACFTU (All-China Federation of Trade Unions), ACWF (All-China Women's Federation), China Red Cross and CYL (Communist Youth League) to sub-contract functions to other organizations. Illustrative of this were initial overtures made by Guangdong Trade Union towards labour NGOs in the summer of 2011 around sub-contracting services. ${ }^{51}$ In November 2011 the Guangdong Civil Affairs director announced that regulations would be altered to allow more than one trade association per sector, a significant move promising to undermine the corporatist intent of Article 13 of existing regulations. ${ }^{52}$ Furthermore, the provincial director of Civil Affairs urged the government to sub-contract more social services. In spring 2012 the Guangdong government continued with this liberalizing path when it issued new fund-raising regulations that would enable social organizations, people's non-enterprise units and non-profit public institutions to fundraise publicly. ${ }^{53}$

Summing up, under the $\mathrm{Hu}-\mathrm{Wen}$ leadership significant steps were taken at central and local levels through institutional layering and bounded adjustment to promote a more enabling regulatory environment for selected social organizations that would then have the legal status to bid for sub-contracting service delivery. These moves became subsumed under a broader double-edged narrative of social management, encapsulating central government goals of a more serviceand people-oriented government that drew on social forces. But, it also expressed a deep concern about domestic unrest, and a strong desire to maintain social control, and ultimately the legitimacy of the Party. In this narrative, social work and civil society were to become strategic tools in maintaining social order.

\section{9-2010: Initiatives related to international actors}

The growth of a service-oriented, non-governmental stratum of welfare service providers required not only a more conducive regulatory framework but also a financial

50 Interview, academic, Beijing, 23 July 2012.

51 Interviews, academic, social activist, Guangdong, August 2011.

52 ICNL 2013.

53 Ibid. 
system to support this. The issue at stake was not just economic but also political. Many welfare-focussed NGOs relied on outside funding sources, such as foreign foundations, embassies and development agencies. This was not just because they were not allowed to raise public funds, but also because there was little public understanding or trust in NGOs, to become a reliable or sufficient revenue source. Moreover, for public security officials, domestic groups receiving funds from abroad were inherently suspect. Disentangling this security concern from the task of creating a more enabling regulatory environment was the crucial Gordian knot that the $\mathrm{Hu}-$ Wen leadership aimed to unravel. Experimentation with direct registration at local civil affairs offices along with revisions in the foundations' regulations formed a twopronged strategy to fashion a more buoyant civic welfare infrastructure under the MOCA, promoting greater public trust in foundations and NGOs that could then solicit more public funds for social welfare provision.

However, the issuing of the Notice on "Issues Concerning the Administration of Foreign Exchange Donated to or by Domestic Institutions" by the State Administration of Foreign Exchange in 2009, effective from March 2010, was a constraining measure that aimed at controlling the direction and type of foreign funding entering China. The new regulations require donated funds to be channelled through a foreign exchange bank account and documentation of cooperation to be notarized by the domestic and international organization in China. These were particularly relevant for civic organizations dependent on foreign funding such as those addressing marginalized and often politically sensitive issues. ${ }^{54}$ From an administrative perspective, these mark an attempt to establish nationwide rules about the transfer and use of foreign funds. From a security perspective, the regulations reflect concerns around domestic unrest, particularly in border areas, and the perceived influence of foreign institutions, especially those with a democracy agenda such as the International Republican Institute. ${ }^{55}$ Indeed, following the Colour Revolutions a Party/government Working Group for Liaising with NGOs (Feizhengfu zuzhi lianxi gongzuo huiyi 非政付組织联系工作会仪) was established at national, provincial and county levels, including officials from public and state security agencies and civil affairs. ${ }^{56}$

The issuing of the 2010 foreign exchange regulations reflected these underlying anxieties as China became more globally exposed. Chinese social organizations feared that notarization would make it more difficult to obtain foreign funding and jeopardize their activities. One interviewee interpreted the new regulations as a deliberate move to "chop off the feet of the movement" and clamp down on rights activists. ${ }^{57}$ Indeed, rights-focused NGOs such as Yirenping were no longer able to receive foreign funds, particularly from the US National Endowment for Democracy. ${ }^{58}$ Parallel to the Notice came also the first

54 Howell 2015; Howell 2016.

55 Interview, foreign foundation, April 2015.

56 Interview, labour academic, Beijing, 25 July 2012.

57 Interview, labour academic, Beijing, 25 July 2012.

58 Ford 2010. 
regulations governing the registration and management of international NGOs in Yunnan province in December 2009. ${ }^{59}$ Requirements that international organizations report to and gain local government approval for every project and partnership caused alarm amongst academics and civil society organizations, who were suspicious of government intent. These regulations were an experimental precursor to the Foreign NGO Law passed seven years later in May 2016 under the Xi administration that was determined to mitigate the influence of potentially destabilizing external forces in China.

\section{Drafting a Charity Law}

Whilst three of the key initiatives promoted in the $\mathrm{Hu}-$ Wen period were institutionalized through regulations and notices, the fourth initiative on a charity law suffered considerable delays. Drafting had already begun in 2004 following a special appeal to the National People's Congress (NPC) by the Legislation Committee for Civil Affairs. ${ }^{60}$ The draft was completed in 2006, and the aim was to complete legislation in 2009 but the State Council did not grant its approval. The law continued to stall, due in part to administrative backlogs and contentious issues that changed over time, ranging from the definition of charity to the dual management system of social organizations and the handling of overseas NGOs. ${ }^{61}$ Although the 2010 NPC reports suggest general agreement over the draft content, there was little headway that year, even though it was included in the NPC legislative plan. However, the spate of charity scandals in 2011, including the Chinese Red Cross, China-Africa Hope Project and Charities Foundation - all GONGOs - provided a strong impetus for pushing forward the law. ${ }^{62}$ For Party leaders to advance welfare reform with non-governmental actors playing a supplementary role, it was vital that there was public and government confidence in the governance of domestic foundations and charities. Public donations to the Chinese Red Cross fell dramatically following the scandal, and it has struggled since to recoup previous levels of public donations and confidence. ${ }^{63}$ These incidents made it increasingly urgent to put in place a comprehensive Charity Law. In the meantime the MOCA issued new regulations in July 2012 requiring charitable foundations to enhance transparency by regularly publishing details of donations and expenditures. ${ }^{64}$

\section{Impact of Hu-Wen Initiatives}

The key initiatives on foundations, registering social organizations and the draft charity law were pivotal in crafting a more favourable regulatory environment for

59 These were the "Yunnan Province Interim Regulations standardising International NGO Activities."

60 People's Daily 2011, 7 September.

61 Cheng 2013.

62 Tiezzi 2014.

63 Xin 2014.

$64 \mathrm{Yu} 2012$. 
social organizations. This not only fostered the rapid development of private foundations but also enabled more service-oriented social organizations to gain legal status. However, as described below, it also led to further institutional turf battles and the concomitant start of a selective cyclical downturn, targeting various advocacy and rights organizations over service-delivery organizations.

Since the implementation of the 2004 Regulations on Foundations, domestic foundations in China tripled from 892 to 3,029 in 2012. ${ }^{65}$ In July 2009 Shenzhen municipal government became the first local authority with the power to approve the creation of public fund-raising foundations. This enabled the One Foundation to end cooperation with the Chinese Red Cross as a private charitable project and to register as an independent public fund-raising foundation in January 2011. ${ }^{66}$ However, there were very few foundations like the One Foundation, established by film celebrity Jet Li, which supported social organizations working on sensitive issues such as migrant workers or HIV/AIDS.

$\mathrm{The} \mathrm{Hu}-$ Wen leadership presided over a substantial rise in both registered and unregistered social organizations addressing issues around poverty, inequality and marginalization. Between 2002 and 2012 registered social organizations doubled in number, from 244,509 to over $499,268,{ }^{67}$ reflecting both increasing government tolerance towards welfare-oriented NGOs and also state incapacity to control their development.

Experimentation with easing registration requirements for selected social organizations led to further growth in registered social organizations submitting files for registration, though exact figures on applications and approval rates across China are not yet available. In the final year of $\mathrm{Hu}-\mathrm{Wen}$ 's rule, the MOCA approved the extension of these rules nationwide, reflecting confidence in and commitment to a welfare-focused, service-oriented civil society. Nevertheless, both social organizations and local officials were wary initially of proceeding because of the lack of implementation detail, the practical difficulty of distinguishing between services-oriented and advocacy, rights-based groups, which often fused these roles, and a potential policy reversal with the forthcoming leadership change.

Whilst civil society organizations and academics welcomed the move to relax registration requirements for social organizations, they also harboured suspicion that this was a government ploy to increase control over society and prevent organizations from receiving international funds. ${ }^{68}$ As the new requirements applied only to service-delivery type social organizations, those groups engaged in sensitive, rights-based work feared that this heralded a more repressive environment for their activities. Indeed such suspicions gained further support with the

65 MOCA Statistical Yearbook 2012: 155; China Statistical Yearbook, 2013: 783.

66 Yin 2011.

67 These statistics refer to the aggregate of the categories of social organizations, people's non-enterprise units and foundations. See China Statistical Yearbook, 2013: 770; China Civil Affairs Yearbook, 2012: 155 .

68 Interviews, Guangdong August 2011, Beijing July 2012. 
concurrent clampdown on labour NGOs and environmental groups from 2012 onwards.

Furthermore, new institutional developments added to delays and suspicions about intent and implementation processes. In the $\mathrm{Hu}-\mathrm{Wen}$ leadership's final year the Party created the central Social Work Commission (shegong wei 社工委) to oversee the work of sub-contracting services to NGOs, with provincial equivalents established first in Shanghai, then Guangzhou and Beijing. As these new-fangled Commissions were Party organs with higher authority than governmental agencies, they soon led to turf wars with local civil affairs bureaux. In Shanghai the provincial commission had a short life when the government soon abandoned this, apparently because the Civil Affairs Bureau was considered effective enough without any higher-level supervision. In contrast, in Beijing the municipal Party committee was keen to have the committee as it was less convinced about the performance of the Civil Affairs Bureau. ${ }^{69}$ In Guangzhou, where the forward-looking governor, Wang Yang, was promoting a raft of social reforms, there was reportedly tension between the committee and Civil Affairs Bureau over the distribution of funds, each seeking a larger share. ${ }^{70}$ There were also reportedly conflicts between the Party and different government departments as the Commission had more resources, authority and decision-making power. ${ }^{71}$

Further complications arose when a parallel commission appropriated the language of "social construction," which like "social management" had associations with social stability. The Politics and Law Commission (Zhengfa wei 政法委), headed by Zhou Yongkang, then Minister of Public Security, filtered the concept "social construction" into the discourse of newly established "social stability" (wei wen 维稳) government sections. ${ }^{72}$ The Politics and Law Commission had greater authority and resources than the Social Work Commission. ${ }^{73}$ In 2012 discussions grew apace about whether to merge the Politics and Law Commission into the Social Work Commission because of concerns about terrorism and security. Awareness of these developments among civil society activists also lay behind concerns that easing registration requirements might have a double purpose of instrumentalizing social organizations for service delivery and repressing groups with a rights-based agenda, heralding a selective cyclical downturn in the development of social organizations.

As described above, there was little progress in passing a Charity Law, despite the 2011 charity scandals and government awareness of its urgency. The law stalled in the $\mathrm{Hu}-$ Wen period partly because of the backlog of proposed legislation and partly because of ongoing government uncertainty and anxiety about

69 Interviews, academic, Beijing, 23 July 2012; labour NGO leader, Beijing, July 2012.

70 Interview, academic, Guangdong, April 2013.

71 In Beijing, for example, there are 100 staff in the committee, focussing solely on community work and NGOs, and not on other traditional civil affairs tasks like social relief.

72 Interview, social policy academic, Beijing, 23 July 2012

73 Interview, labour scholar, Beijng, 25 July 2012. 
how much independence civil society organizations should be permitted to enjoy. As Zheng Gongcheng 郑功成, member of the NPC Standing Committee and Legislation Committee for Civil Affairs, commented in autumn 2011, "the Chinese government still does not know exactly how to handle the relationship between government and charity organizations." 74 Faced with this legal limbo, Zheng nevertheless encouraged local governments to establish their own regulations for charity work so that the lack of a nationwide law would not impede building a civic welfare base. Taking quick advantage of this cue, Jiangsu province, a leader in raising philanthropic funds, became the first province to pass local regulations on charities, a process of opportunistic layering. ${ }^{75}$

$\mathrm{The} \mathrm{Hu}-$ Wen period has thus been pivotal in crafting a more favourable regulatory environment that can facilitate greater welfare provider capacity, specifically private foundations and non-governmental service-delivery social organizations. The new leadership under President Xi Jinping has so far demonstrated a willingness and enthusiasm for consolidating this institutional edifice to roll out welfare services sub-contracting. In March 2013 the State Council indicated that it would bolster the development of civil society as part of its plan for state restructuring and transfer of government functions. ${ }^{76}$ Indeed in March 2013, the Vice-Minister of Civil Affairs, Li Liguo 李立国, emphasized at a news conference in Beijing the growing importance of a charity sector, "Charity organizations have become the major force in the development of the country's charitable undertakings and they now face a 'spring for development'."77 This plan aimed to establish four categories of NGOs, namely, industrial associations, charities, community services and science and technology associations that could forgo finding a supervisory government agency. In July 2013 Guangdong, a pioneer in governance reform, issued regulations for eight types of NGOs to register directly. The Decision at the Third Plenum of the 18th Central Party Committee in November 2013 further endorsed this direction, affirming that selected organizations such as charities, philanthropic organizations and community organizations could "directly apply for registration" and that "social organizations should be commissioned to provide public services." ${ }^{78}$ Whilst this points to strong support for a service-oriented civil society, it has also been counterbalanced by an intensive clampdown in 2015 and 2016 on the internet, on dissidents and on civil society groups using a rights-based agenda.

At the end of the $\mathrm{Hu}-\mathrm{Wen}$ period poverty and inequality continued to be a thorn in the side of the CCP. In his opening speech at the 3rd Plenum in November $2013 \mathrm{Li}$ Keqiang 李克强 stated that 200 million people still

74 Renmin ribao 2011, 7 September.

75 CCTV 2013.

76 He 2013.

77 Rong 2013.

78 See Decision of the 3rd Plenum of the 18th Central Committee of the CCP, Section XIII Making Innovations in the Social Governance System. 
lived in poverty. ${ }^{79}$ However, such a high figure reflects the politicized nature of Chinese poverty lines, which have generally been set lower than international standards, to reduce the apparent numbers of poor people, ${ }^{80}$ thus earning China global praise. Government leaders also use higher figures for reasons such as reinforcing the idea of China as leader of developing countries. Nevertheless, this does suggest that the $\mathrm{Hu}-$ Wen period was not able to make a significant dent in persistent poverty or indeed inequality, which continued to have a high Gini co-efficient of 0.45 .

Clearly developing a civic welfare infrastructure alone is unlikely to have a major impact on levels of poverty and inequality, for which a far broader combination of economic, social and political policies is necessary. In addition the contractual arrangements will need refinement, not least to address the shortterm nature of current contracts - usually only one year long - and the impact of this on organizational sustainability, quality and continuity of care, ${ }^{81}$ as already experienced in other contexts with much longer histories of subcontracting. The scaling up of NGOs in China for service delivery will require considerable capacity-building, whilst foundations have yet to gain public trust. Nevertheless, the fashioning of a civic welfare infrastructure is significant in that it lays the systemic, regulatory and organizational basis for implementation of welfare policies by non-governmental actors and thereby extends the range and breadth of provider capacity. It is thus too soon to cast final judgement on the contributions of the $\mathrm{Hu}$-Wen period to broader development of a welfare system and achieving reductions in poverty and inequality.

\section{Conclusion}

Though some China observers have criticized the $\mathrm{Hu}-\mathrm{Wen}$ leadership for a lacklustre performance, it was during their office that significant advances were made in developing rules governing a more robust system of welfare provision drawing on the energies of civic actors. Leadership tropes such as "harmonious development" and "people-centred development" were important framing devices for institutional change to reduce poverty and inequality. Central to this were the initiatives aimed at building a civic welfare infrastructure, such as the 2004 Foundations regulation, the bounded adjustment of regulations governing the registration of selected social organizations, and the drafting of a Charity Law in 2006. New regulations on the transfer of foreign funds to social organizations in 2010 and experimentation in registering international NGOs marked an attempt to put sufficient order into engagement with foreign organizations to maintain perceived benefits, whilst tightening control over organizations assessed as regime-threatening.

79 Xinhua 2013, 2 November, Li Keqiang's speech at opening ceremony of 21st Century Council Beijing Conference, BBC SWB

80 Zhang et al 2014.

81 Interview, social organization leaders, Taicang, April 2016. 
These initiatives have proved pivotal in developing a civic welfare infrastructure, addressing serious supply-side issues and seeding experimentation in welfare services sub-contracting. Though the Charity Law never moved beyond a draft, it did come to fruition in the Xi administration in March 2016, significantly setting the legal framework for non-governmental welfare provision. The Xi administration also gave a further boost to sub-contracting services to selected groups by rolling out the policy across China, whilst simultaneously curbing foreign funding through the new restrictive Foreign NGO law and strictly requiring registered social organizations to form a party cell.

The interaction between three sets of bureaucratic politics revolving around security and welfare, state-society relations and domestic and external relations informed the development of these initiatives. Competing pressures to maintain social control and stability, ultimately the Party's legitimacy, and the desire to develop a new social welfare model, in turn shaped the formulation and implementation of these rule changes. Though Jiang Zemin called for involving social forces more in resolving public issues, security concerns outweighed any determined push to relax the regulatory environment for civic organizing. It was in the $\mathrm{Hu}-\mathrm{Wen}$ period that these dual imperatives crystallized for the first time the CCP's strategic vision of civil society as one deploying social organizations instrumentally for welfare and stability purposes, whilst repressing activities around advocacy and rights.

This welfarist incorporation agenda advanced further in the new Xi leadership that was keen to improve welfare services both to satisfy a more demanding middle class and allay social unrest in a context of global recession. However, the strategy was qualitatively different in several ways: first, it restored the balance towards security interests as reflected in the most sustained and severe crackdown on rights-based and advocacy groups since 1989; second, the strategy became encapsulated within a broader agenda of Party cleansing and institutional strengthening; and third, it signalled that any policy influence or change was to emanate from within the Party, not through independent initiatives of civil society actors.

In analysing the construction of a civic welfare infrastructure, the application of gradual institutional change theory proved useful in understanding institutional change in an authoritarian context. Some theoretical refinement such as the intermediate categories of bounded adjustment and opportunistic layering served to capture the subtle dimensions of institutional change. Further research in other policy areas could demonstrate the wider usefulness of gradual institutional change theory in authoritarian contexts.

Under the Xi leadership we can expect the development of a civic welfare infrastructure to continue to be driven by competing pressures of stability and welfare reform, and informed by the dynamics of three sets of politics. The implications of this for a broader rights-based, civic realm is less optimistic, however, given that the $\mathrm{Xi}$ administration has presided over the most enduring and severe crackdown on rights-based civil society groups since 1989. Nevertheless, the $\mathrm{Hu}-\mathrm{Wen}$ 
leadership took significant steps in fashioning an architecture of civic welfare provision that should not be lightly dismissed.

\title{
Acknowledgement
}

This research was funded by the United Kingdom's Economic and Social Research Council through grant ES/J012629/1. The author thanks the two anonymous reviewers for their constructive suggestions.

\section{Biographical note}

Jude HOWELL is professor of international development at the department of international development, London School of Economics, UK. She has written extensively on issues relating to civil society and governance, international development, welfare and authoritarianism, and counter-terrorism and aid. Her forthcoming book co-authored with Xiaoyuan Shang and Karen Fisher is NGOs and Accountability in China: Child Welfare Organisations, Palgrave Press. She has recently been awarded an ESRC research grant for research into the Politics of Sub-contracting Welfare Services to NGOs in China. She is series editor of a book series on Non-Governmental Public Action published by Palgrave Press, in which her book The Global War on Terror, Aid and Civil Society (with Jeremy Lind), 2009, appears.

\begin{abstract}
摘要: 自 2015 年以来, 维权性的非政府组织、律师、女权主义者和新闻工 作者正经历着自 1989 年以来最严厉的官方压制。与此同时, 习李政府也 推动了一系列的法律、政策和新规使服务导向的非政府组织能够通过申请 政府合同的方式提供福利服务。这种看似矛盾的“福利性吸纳”政策可以追 溯到胡温时期。尽管胡温时期曾致力于解决贫困和不平等，但这一时期仍 然被视为一个沉闷低迷的时代。通过吸收服务性非政府组织来实现福利供 给多元化是一种复杂的政治基础性活动。通过深入考察这一活动, 本文认 为, 对胡温时期需要给与更加全面的评估。本文考察了三类影响这一政策 过程的政治活动：跨组织政治活动; 国家行动者与非国家行动者的政治活 动; 国内与国外的政治活动。另外, 本文还探讨了主要政治行动者为达成 其目的所采纳的渐进式制度变迁的过程。
\end{abstract}

关键词: 非政府组织; 福利性吸纳; 制度变迁; 习近平; 胡锦涛

\section{References}

Béland, Daniel, Philip Rocco and Alex Waddan. 2016. "Reassessing policy drift: social policy change in the United States." Social Policy and Administration 50(2), 201-218.

Brown, Kerry. 2012. Hu Jintao: China's Silent Leader. Singapore: World Scientific Publishing Company, Singapore.

Brown, Kerry. 2013. "What did Hu Jintao and Wen Jiabao do for China," pp. 1-4, www.bbc.co.uk/ news/world-Asia-China-21669780, 14 March 2013. Accessed 8 May 2016. 
Campbell, John L. 2004. Institutional Change and Globalization. Princeton: Princeton University Press. CCTV.com "Jiangsu province passes first local regulation on charity," 25 January 2010, www. English.CCTV.com/20100125/102221.shtml. Accessed 30 December 2013.

Chan, Chak Kwan, King Lun Ngok and David Phillips. 2008. Social Policy in China: Development and Well-Being. Bristol: Policy Press, 27-44.

Cheng, Fen. 2013. "China's long road to the Charity Law." Beijing: China Development Brief (Winter).

China Development Brief, 2004, "Blurred law may be better than none," June 2010. Accessed 26 December 2013. www.chinadevelopmentbrief.cn/wp.content/10/International.

Cohen, David. 2011. "Decoding 'Social Management'." The Diplomat. 21 September. www. thediplomat.com/2011/09. Accessed 25 November 2013.

Day, Alexander F. 2013. The Peasant in Post-Socialist China: History, Politics and Capitalism. Cambridge: Cambridge University Press.

Dickson, Bruce J. 2008. Wealth into Power: The Communist Party's Embrace of the Private Sector. Cambridge: Cambridge University Press.

Fewsmith, Joseph. 2012. '“Social Management' as a way of coping with heightened social tensions. China Leadership Monitor 36, 6 January, 1-8. www.chinafile.com/library/reports/socialmanagement-way-coping-heightened-social. Accessed 24 December 2013.

Ford, Peter. 2010. "Law chokes Chinese NGOs' foreign funding." Christian Science Monitor, www. CSMonitor.com. Accessed 7 August 2014.

Hacker, Jacob S., 2010. "Policy drift: the hidden politics of US welfare state retrenchment." In W. Streeck and Kathleen Thelen (eds.), Beyond Continuity: Institutional Change in Advanced Political Economies. Oxford: Oxford University Press.

Hall, Peter A., and Rosemary Taylor, 1996. "Political science and the three new institutionalisms." Political Studies 44(5), 936-957.

He, Dan. 2013. "New rules for NGOs to improve operations." China Daily, 17 April.

International Center for Not-for-profit Law, (ICNL) 2013, NGO Law Monitor, June www.icnl.org. Accessed December 2013.

He, Zengke. 2015. Zhonggong de zhili yu shiying: bijiao de shiye (Governance and Adaptation of the Chinese Communist Party: A Comparative Perspective). Beijing: China Compilation and Translation Bureau.

Hildebrandt, Timothy. 2013. Social Organisations and the Authoritarian State in China. Cambridge: Cambridge University Press.

Howell, Jude. 1997. 'Post-Beijing reflections: creating ripples but not waves." Women's Studies International Forum 20(2), 235-252.

Howell, Jude. 2007. "Civil society in China: chipping away at the edges." Development 50(3), 17-23.

Howell, Jude. 2012. "Civil society, corporatism and capitalism in China." The Journal of Comparative Asian Development 11(2). December, 271-297.

Howell, Jude (ed.). 2013. Non-governmental Public Action and Social Justice. Basingstoke, UK: Palgrave Macmillan.

Howell, Jude. 2015. "Shall we dance? Welfarist incorporation and the politics of state-labour NGO relations." The China Quarterly 223, 702-723.

Howell, Jude. 2016. "Adaptation under scrutiny: peering through the lens of community governance in China." Journal of Social Policy 45(3), 487-506.

International Centre for Non-Profit Law (ICNL). 2013. NGO Law Monitor, www.icnl.org.

Jia, Xijin, and Su Ming. 2009. Final Report on Government Procurement of Public Services, P.R. China. June. Asia Development Bank. 1-34.

Jing, Yijia, and Gong Ting. 2012. "Managed social innovation: the case of government-sponsored venture philanthropy in Shanghai." Australian Journal of Public Administration 71(2), 233-245.

Kaufman, Joan. 2012. "The global women's movement and Chinese women's rights." Journal of Contemporary China 21(76), 585-602. 
Lampton, David. 1987. "Chinese politics: the bargaining treadmill." Issues and Studies 23(3), 11-41. Lee, Ching Kwan. 2007. Against the Law: Labour Protests in China's Rustbelt and Sunbelt. Berkeley and Los Angeles: University of California Press.

Li, Cheng. 2013. "Rule of the Princelings." The Cairo Review of Global Affairs, Brookings Institute, Washington, DC, www.brookings.edu/research/articles/2013/02/china-xi-jinping-li. Accessed 2 May 2016.

Lieberthal, Kenneth, and David M. Lampton (eds.) 1992. Bureaucracy, Politics and Decision-making in Post-Mao China. Berkeley, CA: University of California Press.

Lu, Mai, and Feng Mingliang. 2008. "Reforming the welfare system in the PRC." Asian Development Review 25(1-2), 58-80.

Mahoney, James, and Kathleen Thelen (eds.). 2010. Explaining Institutional Change: Ambiguity, Agency and Power. Cambridge: Cambridge University Press.

Ostergaard, Clemens Stugge 2004. "Governance and the political challenge of the Falun Gong." In Jude Howell (ed.), Governance in China. Lanham, MD: Rowman and Littlefield, 207-225.

Pei, Minxin. 1998. "Chinese civic associations: an empirical analysis." Modern China 24(3), 285-318.

Pierson, Paul, 2000, "The limits of design: explaining institutional origins and change." Governance: An International Journal of Policy and Administration 13(4), 475-499.

Rong, Xiandong. 2013. "China vows to boost charities," China Daily, 13 March, www.chinadaily. com.cn/2013npc, Accessed 24 December 2013.

Saich, Anthony. 2008. Providing Public Goods in Transitional China. New York: Palgrave.

Shieh, Shawn, and Signe Knutson. 2011. "The roles and challenges of international NGOs in China's development, Special Report. China Development Brief, 15-16.

Shieh, Shawn, and Deng Guosheng. 2011. "An emerging civil society: the impact of the 2008 Sichuan earthquake on grassroots associations in China." The China Journal 65, 181-194.

Simon, Karla W. 2009. "Regulation of civil society in China: necessary changes after the Olympic Games and the Sichuan earthquake.” International Journal of Civil Society Law 8(2), 60-89.

Spires, Anthony J. 2011. "Contingent symbiosis and civil society in an authoritarian state: understanding the survival of China's grassroots NGOs.” American Journal of Sociology 117(1), 1-45.

Teets, Jessica C. 2009. "Post-earthquake relief and reconstruction efforts: the emergence of civil society in China?" The China Quarterly 198, 330-347.

Tiezzi, Shannon. 2014. "Charities and corruption in China," The Diplomat, 13 August.

Xin, Zhiming. 2014. "Red Cross scandal." China Daily, 7 August.

Yin, Pumin. 2011. "A new dawn for NGOs: registration requirements relaxed for charity work," Beijing Review 31, 4 August.

Walker, Kathy Le Mons. 2006. “'Gangster Capitalism' and peasant protest in China: the last twenty years." The Journal of Peasant Studies 33(1), 1-33.

Wang Ming and Sun Weilin, 2010. "Trends and characteristics in the development of China's social organisations." The China NonProfit Review (Zhongguo feiyinglie pinglun) 2(2), 153-176.

White, Gordon W., Jude Howell and Shang Xiaoyuan. 1996. In Search of Civil Society. Market Reform and Social Change in Contemporary China. Oxford: Clarendon Press.

Wilson, Scott. 2015. Tigers without Teeth: The Pursuit of Justice in Contemporary China. Lanham: Rowman and Littlefield.

Wong, Christine. 2013. "Financing local government in China: challenges in the era after Hu Jintao and Wen Jiabao." Public Lecture given at Fairbank Centre, Harvard University, 9 October.

Xue, Muqiao. 1988. "Establish and develop non-governmental self-management organisations in various trades." Renmin ribao, 10 October (translated in FBIS, China Report, 88/201).

Yu, Qian. 2012. "Charities get new rules to improve their transparency." Global Times, 30 July.

Zhang, Chunni, Qi Xu, Xiang Zhou, Xiaobo Zhang and Yu Xie. 2014. "Are poverty rates underestimated in China? New evidence from four recent surveys." China Economic Review 31, 410-425. 